\title{
Differences in Counselors' Career Outputs in View of Licensure Status in Malaysia
}

\author{
Ooi Pei Boon, Wan Marzuki Bin Wan Jaafar, and Maznah Binti Baba
}

\begin{abstract}
Malaysia is a rapidly developing country. In the last decade, the availability of counseling services has been getting progressive attention and there arises the question of who govern the standard and practice of the counseling service providers. In Malaysia, school counselors are encouraged to register under the Malaysia Board of Counselor which is subjected to the Counselors Act 1998 or Act 580 of the Laws of Malaysia. This paper aimed to study and examine the licensure status of Malaysia school counselors and its' relation with their career outputs. Three hundred and forty five secondary school counselors in Malaysia responded via paper and online survey. The result shows counselors who are registered with the Malaysia Board of Counselor demonstrated higher levels of job satisfaction, career success, professional commitment and self-perceived employability. The reasons of not registered were also explored and discussed in this paper. The recommendation and suggestions for future policy development and governance were discussed.
\end{abstract}

Index Terms-Career success, counseling, job satisfaction, self-efficacy.

\section{INTRODUCTION}

Malaysia is a fast developing country. With the rapid development, it comes to the issues such as disciplinary issue among teenagers, increase of suicide rates among youth, higher dropped out rate and more. The school counselors are the key player in the Malaysia education system. The school counselors play multiple roles in ensuring the students' welfare and needs are taken care of.

In view of these challenges, school counselors are tasked to prioritize their tasks and duties. The focuses are on character building, leadership development, career development and guidance, individual and group counseling. According to the circulars distributed to schools, Guru Bimbingan dan Kaunseling (Guidance and Counseling teacher) is a full time job where he or she is required to log in 33 periods per week with ten periods for individual guidance and counseling, three periods for group guidance and counseling, ten periods to conduct guidance and counseling modules and balance of ten periods for management and administrative duties.

As a key stakeholder who takes care of the school students' psychological, emotional and career development, it is vital for us to study the individual perception of their competency in conducting and carrying out the said duties and responsibilities assigned.

\footnotetext{
Manuscript received October 15, 2014; revised December 30, 2014.

The authors are with the Faculty of Education, Universiti Putra, Malaysia (e-mail: peiboonooi@hotmail.com, wanmarzuki@upm.edu.my, mazb@upm.edu.my )
}

The concept of self-efficacy has been receiving considerable attention over the past 30 years and wide studied. Albert Bandura first introduced this construct back in 1986. Numerous of research have been carried out in different domains such as mathematics [1], career decision [2], emotional intelligence [3], organizational culture [4] and training [5].

Students, who believe they could excel academically, tend to produce higher academic outcomes, possess higher goals, and assert higher effort and higher level of perseverance when it comes to obstacles [6]. Self-efficacy among school counselors would be an untapped area where it is interesting to study the self- perceived evaluation among school counselors on their abilities and capabilities in carrying out duties and tasks. Self-efficacy may result in career development and decision making of a school counselor. A school counselor who posited higher level of self-efficacy may possess higher goals, displays a higher effort in conducting counseling, gains a greater sense of job satisfaction, higher commitment to the organizational and confidence of other job opportunities outside of the current organization.

Based on such background, this study aimed to study the differences between the registered and non registered counselor and its' relations to career outputs, namely the self-efficacy, job satisfaction, self-perceived employability, career success and professional commitment. A study in this aspect is vital as it provides insight to the current perception of school counselors on the roles and functions of the regulatory body (the Malaysia Board of Counselors). The result will be useful for an in-depth discussion of educational and awareness initiatives of the needs to register with the Malaysia Board of Counselors.

\section{Methodology}

\section{A. Design}

A self-administrated questionnaire and cross sectional study was conducted over the period of three months. The questionnaire was developed after permissions were granted by the respective authors of the said assessment/inventory. The researcher wrote to the authors to obtain approval to use and minor edit to the questionnaire according to the research context. The word "school" was added instead of just solely "organization" to reflect current practice and measure among school counselors in the school setting.

Fourteen (14) states of Malaysia were represented with Kuala Lumpur with the highest response rate $(19.7 \%)$ and lowest with Perlis $(0.28 \%)$. 


\section{B. Participants}

Sample was elected randomly from the school listing made available in the Education Management Information system (EMIS) portal managed by the Ministry of Education (MoE) Malaysia, using fish bowl technique of simple random sampling. Our study targeted on school counselors who are based in the secondary schools from the entire Malaysia.

The participants do not need to be registered counselor under the Malaysia Board of Counselors nor do they need to possess a license under the Malaysia Board of Counselors.

Three hundred and forty five counselors volunteered to participate in current research (71 males, 274 females; average age $=37.08, S D=12.15)$. Among them, 152 participants $(44 \%)$ were registered counselor, and another $193(56 \%)$ did not register with the Malaysia Board of Counselors.

\section{Measurements}

The questionnaire consists of seven sections with the section $\mathrm{G}$ being the demographic segment with sixteen (16) questions.

Section A-the Counseling Self-Efficacy Inventory (COSE) consists of thirty seven (37) items, with five subdomains (microskills, counseling process, difficult client behavior, cultural competency, and awareness of value). Respondents were asked to rate on 6-points Likert scales from 1 (Strongly disagree) to 6 (strongly agree). The instrument which was developed by [7] is being used for training, supervision and research pertaining to counselors' self-efficacy. The COSE does not measure performance, but one's perceived confidence in performing counseling.

Section B- the Counselor Activity Self-Efficacy Scale (CASES) consists of forty one (41) items which was developed by [8]. This is a self-administered instrument where respondents' self-efficacy regarding abilities in performing helping skills, managing the counseling process and handling challenging counseling situations. The instrument has three (3) parts and each part asked the respondents in view of their beliefs to perform various behaviors or particular situation in counseling. The scale ranges from 0 (not confidence) to 9 (completely confidence).

Section C measured the job satisfaction using the Minnesota Satisfaction Questionnaire, short-form. It consists of 20 items and developed by [9]. It runs on five-point Likert-scale with responses varying from 1 (very dissatisfied) to 5 (very satisfied). The short-form of MSQ provides three dimensions, namely a) general satisfaction with the reliability coefficient ranges from .87 to .92 , b) intrinsic satisfaction with the reliability coefficient ranges from .84 to .91 and c) extrinsic satisfaction with the reliability coefficient ranges from .77 to .82 .

Section D measured the school counselors' self perceived employability. It is defined in two folds - the ability one has to keep the job or ability to obtain the job one desired [10] and it is being measured by using the Self-Perceived Employability Questionnaire developed by [10]. This section consisted of 11-items five-point Likert-Scale with responses varying from 1 (strongly disagree) to 5 (strongly agree).

Section E formed by the subjective career success scale, taken from the work of [11] and [12] and it has a total of 8 items. The scale measured how school counselors expect their career success to be mapped out over the career lifespan. Career success is defined as one's judgment of his or her performance or success and individual with higher score feel happier and successful [11]. Question 1 and 2 reflected on current accomplishment, whereas questions 3 to 8 reflected the current emotions on previous accomplishment. Example of question is "I am satisfied with the progress I have made towards meeting my overall career goals". The scale ranged from 1 (strongly disagree) to 5 (strongly agree).

Section F measured professional commitment scale developed by [13] with just eight of the nine items. Adapted from [10], one item "I up this profession to my friend as a great association to be associated with" was replaced with "often I find it difficult to agree with this profession's policy on important matters relating to its members" and was scored reversely. The scale ranged from 1 (strongly disagree) to 5 (strongly agree).

Section $G$ was used as the background questionnaire to collect descriptive characteristic of the participants as well as their registration status and reasons. The following demographic information such as age, gender, race, highest academic qualification, year of experience, current job title, number of job changed, status and needs of counseling supervision and duration, areas of training and state of the workplace were collected for descriptive purpose.

\section{PRocedures}

A pilot test was conducted before the launch of the questionnaire nationwide. The samples of the pilot test were selected based on the school counselors who researcher comes in contact with during the month of August 2014.

The researcher had the questionnaire mail over by email or snail mail. The questionnaire is also made available via technology such as Google Docs, however, only 9 individual utilized such method. The respondents' response is treated ethically and the identity is kept anonymous.

Total list of all school was compiled and the random sampling technique was used to draw the sample of which questionnaire will be distributed. With the population size of 2376 secondary schools [14], a minimum 331 response rate is required. Each set of the questionnaire contained two support letters, one from the Ministry of Education, Malaysia and one from the respective state education department. Each set of the questionnaire contained an envelope with return stamps, addressed to the researcher.

\section{Result AND Discussion}

Some of the data was incomplete and was being treated as missing values and was excluded from analysis. $\mathrm{T}$ test was conducted to examine the difference between the main variables of this study and the gender. No significant difference was found.

\section{A. Difference in Self Efficacy}

An independent sample $t$ test was conducted to examine the difference in self efficacy between the registered and non registered counselors. The result shows that registered 
counselor demonstrated significantly higher counselor self efficacy score as compared to non registered counselors, in both CASES, $t(315)=3.206, p=0.001$ and COSE, $t(293)=$ $5.503, p<0.001$.

With CASES, the mean score for counselors who have registered was $6.62(S D=1.10)$ whereas $6.16(S D=1.29)$ for non registered counselors. With COSE as measurement, registered counselors mean score was $4.38(S D=0.62)$ and 4.01 $(S D=0.57)$ for non registered counselors.

TABLE I: THE MEAN AND STANDARD DEVIATION OF CASES AND COSE

\begin{tabular}{lllll} 
& \multicolumn{2}{c}{ Registered } & \multicolumn{2}{c}{ Non Registered } \\
& Mean & SD & Mean & SD \\
\hline \multirow{2}{*}{ CASES } & 6.62 & 1.10 & 6.16 & 1.29 \\
COSE & 4.38 & 0.62 & 4.01 & 0.57 \\
\hline
\end{tabular}

\section{B. Difference in Outcome Variables}

An independent sample t tests was conducted to examine the difference between the registered and non registered counselors in job satisfaction, self perceived employability, career success and professional commitment.

The result shows that registered counselor has higher job satisfaction, at $t(330)=2.457, p=0.015$ as compared to non registered counselors. The mean score for registered counselors was $4.03(S D=0.52)$ and the mean score for non registered counselors was 3.87 ( $S D=0.62)$.

An independent sample $t$ test was conducted to examine the difference between the registered and non registered counselors in self-perceived employability. The result shows that registered counselor has the highest score in the three subscales, self-perceived employment, at $(271)=2.664 p=$. 0.008 , career success, $t(340)=2.973, p=0.003$ and professional commitment $t(338)=3.907, p<0.001$ as compared to non registered counselors.

In the aspect of self-perceived employability, career success and professional commitment, the mean scores for registered counselors are $3.87(S D=0.55), 3.98(S D=0.69)$ and $4.10(S D=0.55)$ respectively. Meanwhile the mean scores for non registered counselors are $3.72(S D=0.44), 3.76(S D=$ $0.64)$ and $3.87(S D=0.52)$ respectively.

TABLE II: THE MEAN AND STANDARD DEVIATION OF OUTCOME VARIABLES

\begin{tabular}{lcccc} 
& \multicolumn{2}{c}{ Registered } & \multicolumn{2}{c}{ Non Registered } \\
& Mean & $S D$ & Mean & $S D$ \\
\hline Job Satisfaction & 4.03 & 0.52 & 3.87 & 0.62 \\
Self Perceived & 3.87 & 0.55 & 3.72 & 0.44 \\
Employability & 3.98 & 0.69 & 3.76 & 0.64 \\
Career Success & 4.10 & 0.55 & 3.87 & 0.52 \\
Professional Commitment & & & & \\
\hline
\end{tabular}

\section{Reasons for not Registering with the Board of Counselors, Malaysia}

We investigate the reasons of why the counselors are not registered as a counselor with the Malaysia Board of Counselors. The main reasons given were $20.11 \%$ of the respondents are not interested in applying the license, $18.44 \%$ are with others degree, for example the psychology degree, $17.32 \%$ respondents said they did not see the needs in registering themselves with the Malaysia Board of Counselors and $7.26 \%$ said they are not aware of the requirements and $2.23 \%$ of respondents stated that they feel it is too stressful with the process of registration.

From the total of non registered counselors, about $27.37 \%$ stated others as their reasons. The few main other reasons given, are the respondents do not have time to apply (6), the respondents have not received their transcript to register (3), and the respondents have not been selected by the school principal and waiting to be selected (2).

\begin{tabular}{lr}
\multicolumn{2}{c}{ TABLE III: THE REASONS OF NOT REGISTERED } \\
\hline Reasons & Percentage \\
\hline I am not interested in it & 20.11 \\
I am from other degree (example: Psychology & 18.44 \\
degree) & 17.32 \\
I don't see the needs & 7.26 \\
I am not aware about it & 7.26 \\
It is too difficult & 2.23 \\
It is too stressful & 27.37 \\
Others & 100 \\
\hline
\end{tabular}

\section{DISCUSSION}

Findings from the current study provide support in differentiating the self reported performance between registered and non-registered counselors. It appears that counselors who have registered under the Malaysia Board of Counselors possess higher score in the areas measured in relation to one's self estimate of future performance in conducting counseling sessions. By using Counseling Self Estimate Inventory (COSE), registered counselors demonstrated higher self estimation in 1) confidence to execute micro skills, such as paraphrasing and summarizing 2) attending to process, for instance, responding to clients' questions accurately and promptly 3) dealing with difficult clients with strong fundamental of theories and technique, 4) behaving in culturally competent manner in dealing with the minority or clients from different social class and 5) being aware of one's values and free from being judgmental. Two of the main functions of the Board are to oversee and supervise the counselors [15]. Supervision's feedbacks improve counselors' self-efficacy in linear correlation method. Positive feedback will increase counseling self-efficacy and negative feedback will decrease counseling self-efficacy [16]. This mentoring process also provided constant check and balance on the counselors' method, skill, process and behavior demonstrated in the counseling session. The counselors are more aware of own actions and constantly strive to follow and adhere to the standard and guidelines set by the Board.

In another measurement, the Counselor Activity Self-Efficacy Scales (CASES), registered counselors perceived higher level in their own counseling capabilities. This data demonstrated that registered counselors are more confident in using general skills such as attending skill, open 
questions, listening skills, confrontation, role play and developing homework with and for the clients. The registered counselors also perceived themselves as more confident in performing specific tasks such as keeping the session on track and be specific in the treatment goals, help clients to set practical and realistic conceptual plans and assist clients to determine the action required. The registered counselors also perceived themselves higher in capacity in dealing with clients from various backgrounds such as those who is clinically depressed, suicidal or show signed of severe cognitive disturbance. In a research conducted by [17], it is concluded that counselor self-efficacy correlate positively with indexes of both counselor performance and their developmental level. Registered counselors perceived themselves as more capable and confident in performing such tasks with clients from various backgrounds with the skills set mastered and thus increase their performance overall in the session.

With the higher sense of achievement and performance, the sense of job satisfaction is also higher among registered counselors. They portray a higher sense of satisfaction when evaluated in view of intrinsic and extrinsic satisfaction. With the mean score of 4.03 , it demonstrated that registered counselors are satisfied with their aspect of work as compared to non registered counselors whose mean score is 3.87, which indicated they could not decide if they are satisfied or not with their current aspect of the works. According to [18], job satisfaction is significantly correlated to life satisfaction and job performance among teacher. Job satisfaction contributes to the development of positive attitude toward the job. School counselors who have a role too in teaching and often being classified as guidance and counseling teachers may gain satisfaction from the jobs specifically and life satisfaction overall.

The higher score in self perceived employability explained that the registered counselors perceived themselves as possess the higher skills (for example; good sense of knowledge and skill of this helping profession) and other key attributes (such as a strong network with other profession from the field) to find and stay in a job one wants. They may perceive themselves as highly respected in the field and even when there is downsizing in the organization, they are confident that they would be retained as compared to the non registered counselors.

Among the counselors, the registered counselors presented higher scores in career success and professional commitment. They reported overall higher satisfaction when it comes to overall career achievement and success. They are pleased with the progress they made in achieving personal goals, be it salary or managerial position. They are also proud to share with others in a great length of this profession and willing to put in extra efforts and hours, with pride, for this profession. They show a higher level of commitment in making sure this profession turns out to be well and respected.

On the other hands, the reasons of the individual not wanting or able to register may present potential issues to the users (that is the client). The reasons of "I am not interested in it", "I do not see the needs", "I am not aware of it", "It is too difficult" and "It is too stressful" could be addressed with a more vibrant and transparent recruitment and entry process.
The functions, benefits, advantages and roles of the Board shall be made known publicly via various channels, including the social media such as Facebook, Twitter and LinkedIn. Social media such as the above have the viral power of spreading the news and at the same time, gather input from various parties in an instant manner. These platforms, with monitoring, could serve as reference of information and venue for all forms of supports (be it emotional and academic). The Malaysia Board of Counselors does not appear on all three networks mentioned above from the recent check by the researcher. The website homepage of the Board shall also be made more information and interact with the exchange of good practices. Once the entry requirement, selection and interview process are made know, it reduces the fear of "too difficult" or "too stressful". An individual who has succeeded in the interview ,awarded with the licensed status and benefited from the monitoring process of the Board could also share their experience and journey of obtaining the license and how does it assist in them performing their duties and tasks as helping profession in schools. This vicarious learning experience will help to address the issue of lack of awareness or interest in the process. This debuting process may take longer as individual may not see the needs in it immediately, until and unless, the situation demanded them to refer to the Board for guidance and advice.

Any non registered counselors could still extend services, be it individual or group counseling, to any students, as long as it does not threaten the welfare of the students, school and community. However, the data show that registered counselors do possess overall higher scores in all aspects measured. Hence, it is critical for such findings to be studied and used for the benefits of the implementer; the Board and the receiver; the counselors.

\section{CONCLUSION}

This study presented the vital data for the comparison between registered and non registered counselors in view of their career outputs in view of counseling self-efficacy, job satisfaction, self-employability, career success and professional commitment.

It is interesting to note that from the total respondents, only $44 \%$ are registered and those who did not registered provided an insight to the reasons why 1) they are not able to register or 2) they do not want to register. The reasons illustrated could be used by any legislative or governance for any educational and promotional program to increase the awareness of the registration process. It is also important to note that individual perception of their competency in conducting and carrying out the said duties and responsibilities assigned is higher among the registered counselors. The functions and benefit associating with the Board could be made known to the public, in view of statue monitoring and assurance, and to the society of the counselors.

\section{REFERENCES}

[1] G. Hackett and N. Betz, "An exploration of the mathematics self efficacy/mathematics performance correspondence," Journal For Research In Mathematics Education, vol. 20, pp. 261-273, 1989. 
[2] N. Betz, M. Hammond, and K. Multon, "Reliability and validity of five-level response continua for the career decision self-efficacy scale," Journal of Career Assessment, vol. 13, no. 2, pp. 131-149, 2005.

[3] L. Pool and P. Qualter, "The dimensional structure of the emotional self-efficacy scale (ESES)," Australia Journal of Psychology, vol. 64, pp. 147-154, 2012.

[4] M. Simosi, "The moderating role of self-efficacy in the organizational culture-training transfer relationship," International Journal of Training and Development, Blackwell Publishing Ltd, 2012.

[5] S. Tannenbaum and J. Mathieu, "Meeting trainees' expectations: The influence of training fulfillment on the development of commitment, self-efficacy and motivation," Journal of Applied Psychology, vol. 76, no. 6, pp. 759-769, 1991.

[6] A. Bandura, Self-Efficacy: The Exercise of Control, New York: Freeman, 1997.

[7] L. Larson, L. Suzuki, K. Gillespie, M. Potenza, M. Bechtel, and A. Toulouse, "Development and validation of the counseling self-estimate inventory," Journal of Counseling Psychology, vol. 39, pp. 105-120, 1992.

[8] R. Lent, C. Hill, and M. Hoffman, "Development and validation of the counselor activity self-efficacy scale," Journal of Counseling Psychology, vol. 50, no. 1, pp. 97-108, 2003.

[9] D. Weiss, R. Dawis, G. England, and L. Lofquist, "Manual for the Minnesota Satisfaction Questionnaire," Washington: University of Minnesota, 1967.

[10] A. Rothwell and A. John, "Self perceived employability: Development and validation of a scale," Emerald: Personal Review, vol. 36, no. 1, pp 23-41, 2007.

[11] J. Greenhaus, S. Parasuraman, and W. Wormly, "Effects of race on organizational experiences, job performance evaluations and career outcomes," Academy of Management Journal, vol. 33, no. 1, pp. 64-86, 1990.

[12] G. Nabi, "An investigation into the differential profile of predictors of objectives and subjective career success," Career Development International, vol. 4, no. 4, pp. 212-224, 1999.

[13] A Tsui, J. Pearce, and A. Tripoli, "Alternative approaches to the employee-organization relationship: Does investment in employee pay off?" Academy of Management Journal, vol. 40, no. 5, pp. 1089-1121, 1997.

[14] Education Management Information System, Ministry of Education Malaysia. (2014). [Online]. Available: http://emisportal.moe.gov.my/

[15] Counselling teachers need to be registered. (2014). [Online]. Available: http://www.sinarharian.com.my/nasional/guru-kaunseling-perlu-berda ftar-1.256752

[16] J. Daniels and L. Larson, "The impact of performance feedback on counseling self efficacy and counselor anxiety," Counselor Education and Supervision, vol. 41, pp. 120-130, 2001.
[17] L. Larson and J. Daniles, "Review of the counseling self efficacy literature," The Counseling Psychologist, vol. 26, pp. 179-218, 1988.

[18] H. Demirel, "An investigation of the relationship between job and life satisfaction among teachers," Procedia Social and Behavioral Sciences, vol. 116, pp. 4925-4931, 2014.

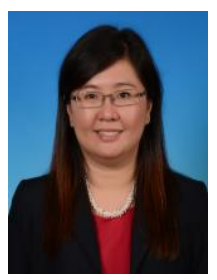

Ooi Pei Boon was born in Taiping, Malaysia. She received her bachelor degree in education, majoring in guidance and counseling and master degree in guidance and counseling both from Universiti Putra Malaysia (UPM). Ooi is currently pursuing her PhD study at the UPM and her interest of study focuses on counselor personal and professional development. Ooi is a certified hypnotherapist with the American Board of Hypnotherapy and registered as a registered and licensed counselor with the Malaysian Board of Counselors.

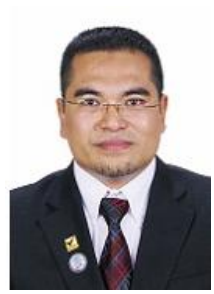

Wan Marzuki Bin Wan Jaafar is a senior lecturer from Department of Counselor Education and Counseling Psychology, Faculty of Educational Studies, University Putra Malaysia. His research interest is in counselor education and supervision, career counseling, development of psychological instrument, and computer application in education. $\mathrm{He}$ is the chair of curriculum standards, counselor registration and licensure for the Malaysia Board of

Counselors.

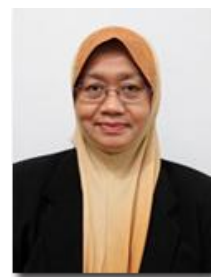

Maznah Baba is currently a senior lecturer in the Department of Counsellor Education and Counselling Psychology. She was awarded a doctoral degree in counselor education from Syracuse University (SU), New York, USA, in 1990. She started her lecturing career at UPM in 1980 after completing her MS in guidance and counselling from SU. She was a technical committee member and one of the module writers of the premarital course for Muslims developed by JAKIM. She was involved with the LPPKN in developing parenting modules and courses. Her current research interests include studying family stress and coping, especially among widows and orphans, and juvenile delinquency. She is a registered (K.B) and licensed counselor (P.A) with the Malaysia Board of Counselors and an Ahli Lembaga Pelawat of the Sekolah Tunas Bakti, Sg. Besi. 